\title{
MARINE TUCUXI DOLPHIN (SOTALIA GUIANENSIS) INJURIES AS A POSSIBLE INDICATOR OF FISHERIES INTERACTION IN SOUTHEASTERN BRAZIL
}

\author{
Mariana Freitas Nery ${ }^{1,2}$, Mariana de Assis Espécie ${ }^{2}$ \& Sheila Marino Simão ${ }^{2}$ \\ ${ }^{1}$ Instituto de Ecología y Evolución, Facultad de Ciencias, Universidad Austral de Chile \\ (Casilla 567, Valdívia, Chile) \\ ${ }^{2}$ Laboratório de Ecologia e Bioacústica de Cetáceos, Departamento de Ciências Ambientais, \\ Instituto de Florestas, Universidade Federal Rural do Rio de Janeiro \\ (BR 465, km 7, Campus Universitário, 23890-000 Seropédica, RJ, Brasil)
}

maribioufscar@yahoo.com.br, mariana_especie@hotmail.com,smsimao@ufrrj.br

Interactions between marine mammals and fisheries have been reported worldwide and may have potential effects on the stability of populations (READ et al., 2006). The International Whaling Commission (IWC) has recognized that mortality of marine mammals in fisheries may be a threat to population stocks, as these interactions are increasing in frequency and intensity (DeMASTER et al., 2001). These interactions with the fisheries can be identified through photograph examination looking for wounds, scars, or entangled gear on beach-cast animals as well by observation of animals in the wild (BAIRD; GORGONE, 2005). Four different types of interactions may occur: entanglement in fishing gear, ingestion of marine debris, harassment, and vessel collisions (MORGAN; PATTON, 1990). Entanglements in fishing gear have been reported for several marine taxa (e.g. NORMAN, 2000; FLORES, 2002; LÓPEZ et al., 2003; REEVES et al., 2003; KOCK et al., 2006) and represent a serious threat to dolphins, especially to those with coastal habitats. Rates and patterns of entanglement-related scarring visible in photographs of animals in the wild may be used to assess the frequency of non-lethal entanglements (ROBBINS; MATTILA, 2001).

The marine tucuxi dolphin (Sotalia guianensis) is a small delphinid that inhabits coastal waters, occupying bays and estuaries where the greatest human demographic concentration on the Atlantic coast can be found (FLORES, 2002), and is listed as insufficiently known by the World Conservation Union (IUCN) (REEVES et al., 2003). Along the Brazilian coast there are resident populations of this species and one of these is concentrated in Sepetiba Bay $\left(22^{\circ} 59^{\prime} \mathrm{S}, 44^{\circ} 03^{\prime} \mathrm{W}\right.$ ) (Fig. 1 ), on the southern coast of Rio de Janeiro State (SIMÃO et al., 2000).

Sepetiba Bay is a semi-closed coastal lagoon with an area of $519 \mathrm{~km}^{2}$ which includes different ecosystems like beaches, islands, rocky cliffs, mangrove and inter-tidal swamps (MUEHE; VALENTINI, 1998). Much of the inlet complex is shallow (approximately $6 \mathrm{~m}$ in depth), but in some isolated areas, particularly between the islands, it can be up to $47 \mathrm{~m}$ deep (MUEHE; VALENTINI, 1998). Sepetiba Bay is surrounded by a metropolitan area and is highly degraded due to habitat loss, overfishing, harbour activities, inputs of metals and organochlorins among others (MARQUES et al., 2002). This area is now becoming a centre of interest with the development of an important harbour (Itaguaís Harbour) and has intense fishing activity year-round.

This short communication reports humaninduced injuries to marine tucuxi dolphins recorded while carrying out photo-identification and behavioral activity surveys in Sepetiba Bay.

From April 2006 to April 2007 a total of 14 boat surveys were undertaken for marine tucuxi dolphins photo-identification, onboard a $7 \mathrm{~m}$ long boat. The effort was not equally distributed along the year and the intervals between consecutive surveys ranged from 2 to 74 days. The boat travelled without any systematic route until one or more groups of dolphins were sighted by trained cetacean observers, which recorded the animals' geographic position using a GPS, time of sighting, group size, and behaviour. Photographs were taken using a Canon EOS 20D Digital camera with Canon zoom EF 75-300 mm. In laboratory the pictures were sorted and analysed using the software Adobe Photoshop 7.0 and Windows Picture and Fax Viewer following Mazzoil et al. (2004). Good-quality pictures (well focused, with enough light, less blurring) were used to look for possible identification features like nicks and notches on dorsal fins. Scars and injuries on dolphin bodies were used as auxiliary marks for the photoidentification of the animals. The photographs of the dolphins were used to assess whether animals in Sepetiba Bay exhibit marks of injuries caused by anthropogenic activities. 

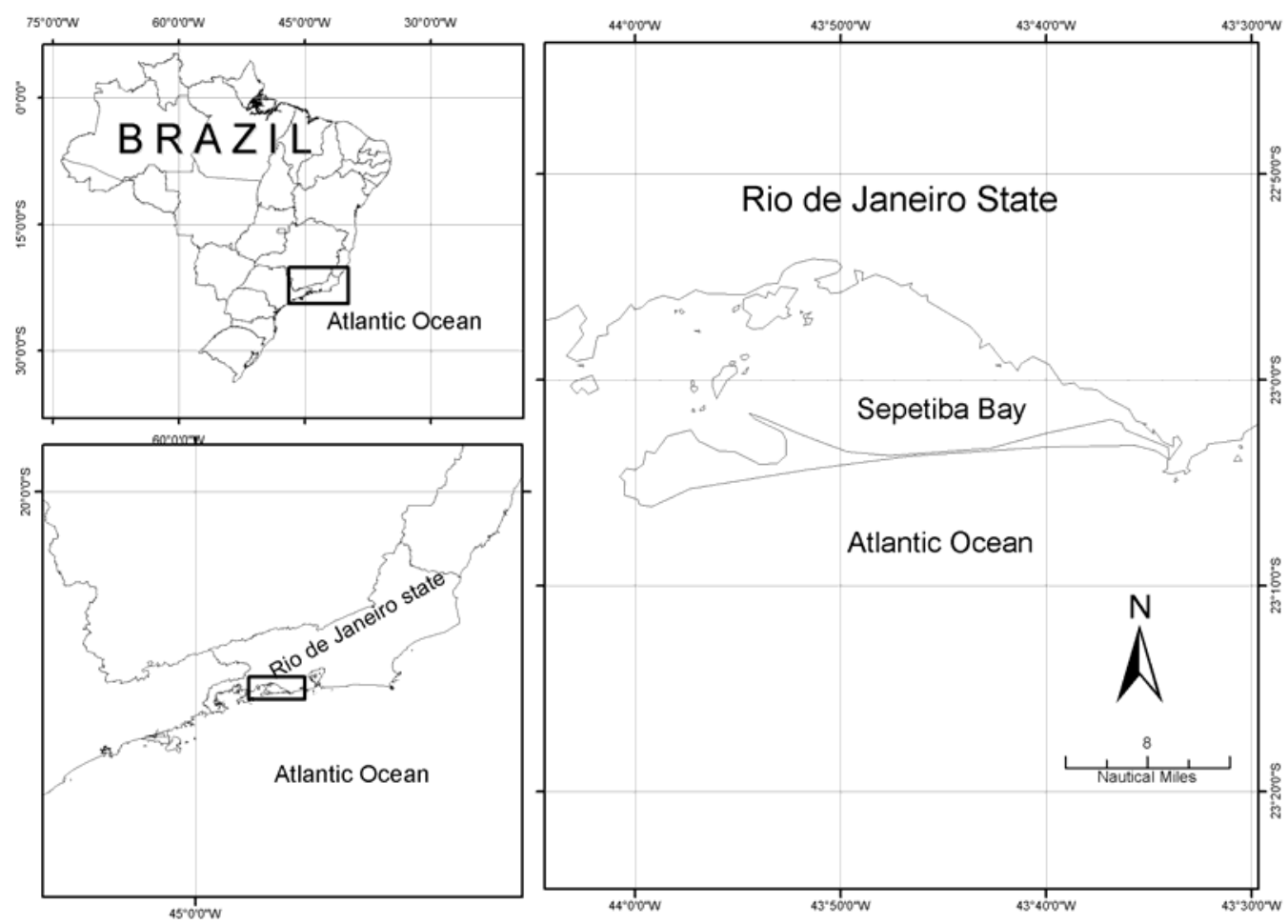

Fig. 1. Map of Sepetiba Bay $\left(22^{\circ} 59^{\prime} \mathrm{S}, 44^{\circ} 03^{\prime} \mathrm{W}\right)$, south-eastern Brazilian coast, where marine tucuxi photo-id surveys were conducted between 2006 and 2007.

We spent $59.3 \mathrm{~h}$ on direct observation (time spent observing dolphins) out of $77.2 \mathrm{~h}$ of field effort. The group size ranged from 2 to 200 individuals $(80.5$ \pm 11.1 ). A total of 382 animals were identified and catalogued, with a resighting index of $40.3 \%$. From these catalogued individuals, $19(5.0 \%)$ dolphins exhibited non-natural marks in the dorsal fin as a result of interaction with gillnets or other fishery artefacts. These non-natural marks include missing entire dorsal fin or partially bent over, and cut-like wounds probably caused from fishing gear. Some of the animals still had part of a net with nylon fragments attached to its bodies. Table 1 shows the frequency of such injuries.

Table 1. Frequency of injuries found on dolphins of Sepetiba Bay.

\begin{tabular}{ccc}
\hline \hline Injury & Missing dorsal fin & $\begin{array}{c}\text { number } \\
\text { of } \\
\text { dolphins }\end{array}$ \\
\hline $\begin{array}{c}\text { Fishery } \\
\text { interaction }\end{array}$ & 1 \\
& $\begin{array}{c}\text { Partially bent over } \\
\text { Marks from fishing gear }\end{array}$ & 6 \\
& total & 12 \\
& & 19
\end{tabular}

We found two dolphins with fishhooks attached to their dorsal fin (Fig. 2). Probably these dolphins were caught by a longline fishing artifact and the hook was attached to their dorsal fin accidentally. According to the local fishermen, longline fisheries are used in the area to capture rays. One dolphin without its dorsal fin was catalogued. Besides that, we noticed that six animals had the dorsal fin partially bent over. Collapsed or missing dorsal fins have rarely been reported for cetaceans being most frequently in killer whales (Orcinus orca) (STACEY, 1989; VISSER, 1998). All individuals we documented with completely or partially bent-over fin had injuries at the leading edge base of the fin, which is consistent with line or fishing gear injuries documented for other cetaceans (WELLS et al., 1998; ROBBINS; MATILLA, 2001; BAIRD; GORGONE, 2005).

Few published data are available on rates of such dorsal fin disfigurements from other populations of odontocetes. Bigg et al. (1987) working with killer whales (Orcinus orca) in British Columbia, Canada, found a proportion of $0.6 \%$ of animals with marks caused by fishery interaction, which represent 2 animals from 331 identified individuals. Baird and Gorgone (2005) encountered that $3(3.75 \%)$ from 80 individuals of false killer whale (Pseudorca 
crassidens) had dorsal fin disfigurements resulted from fishery interaction. In Brazil, a similar scenario can be found in Guanabara Bay, Rio de Janeiro. Azevedo et al. (2008) studying this marine tucuxi population, established that $7(9.0 \%)$ out of 78 photoidentified and catalogued individuals presented noticeable injuries on their bodies, including cut-like wound, skin ulceration and mutilation. In our study, we found a greater number of animals in absolute numbers but a smaller proportion of injured animals when compared with Guanabara Bay.

In contrast to Guanabara Bay, which is the most degraded area along $S$. guianensis distribution (AZEVEDO et al., 2008), Sepetiba Bay, located at approximately $70 \mathrm{~km}$ south from Rio de Janeiro City, still presents a fairly well preserved environment. However, the geographic proximity of Sepetiba Bay to the Rio de Janeiro metropolitan region has favoured
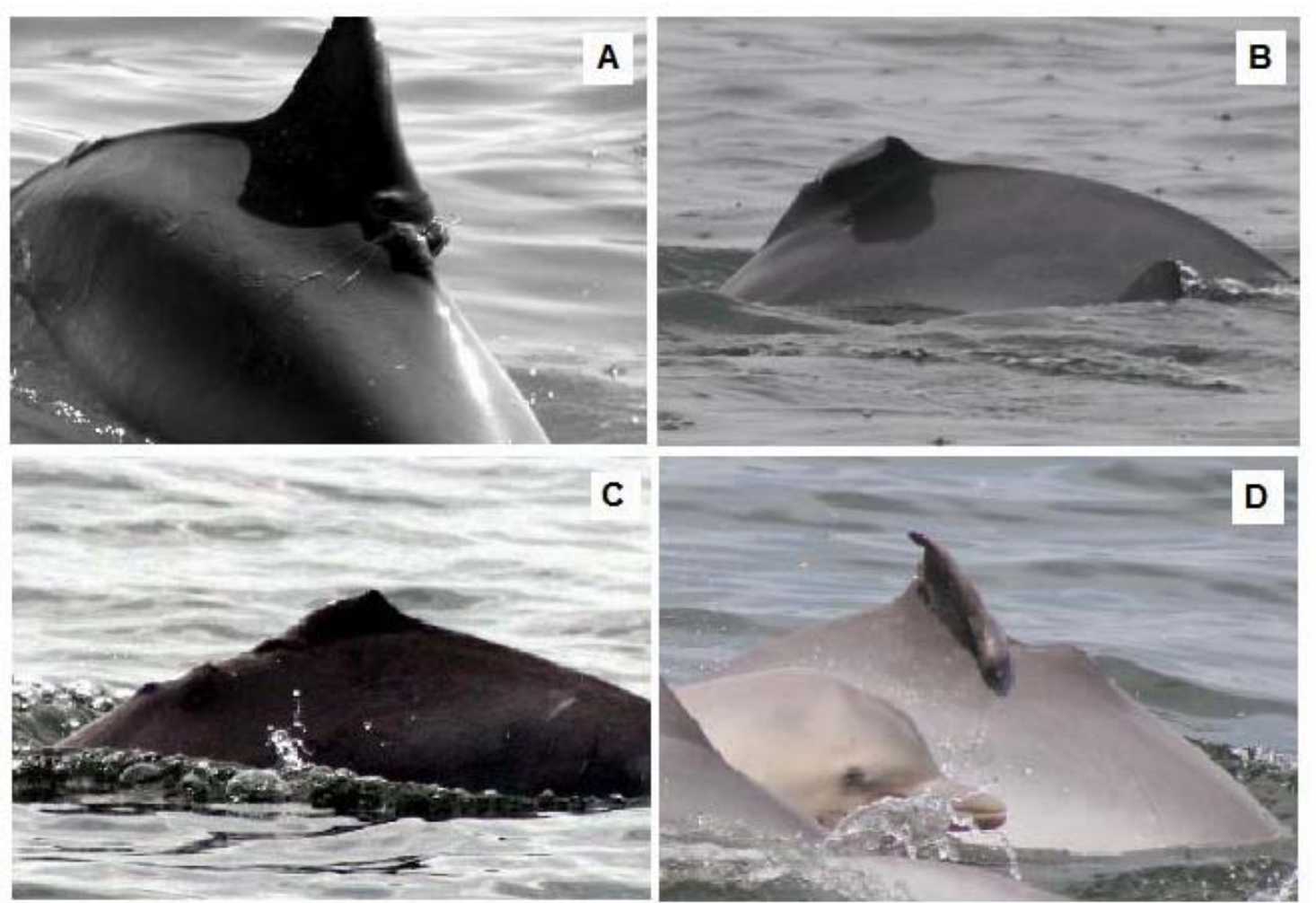

the development of the area and still impulses new projects. In addition to tourism and fishing activities, the bay houses two important harbours and several metallurgic industries on its surroundings. Big cargo ships can be found at Sepetiba Bay, mainly in the central channel that leads to Itaguaí's Harbour and small boats are everywhere. Due to increased levels of boat traffic in this bay, and the use of coastal habitats by marine tucuxi dolphins, they are exposed to higher levels of human activities like other coastal cetaceans (READ et al., 2006). Although the relatively small number of individuals identified to be suffering from these anthropogenic threats, they are an important concern as human activities increases, dolphin injuries may increase as well. It is important to note that observations of animals in the wild with entangled fishing gear are opportunistic and likely reflect only a small proportion of injured animals.

Fig. 2.Individual injuries observed in Sotalia guianensis in Sepetiba Bay. (A) individual with a fishhook attached to its dorsal fin; (B) individual with dorsal fin bent over to left; (C) individual without its dorsal fin; (D) cut-like wound on the base of the dorsal fin.

\section{.}


Dolphin entanglement in fishing gear do not always result in death (PERRIN et al., 1994) and by the nature of our study, we are only looking to nonfatal injuries. Although none of these injuries was immediately fatal, long-term effects on survivorship are still unknown and it is known that fishing gear may cause serious health problem to small cetaceans, since they may acquire infections, exhibit altered behaviour patterns or suffer a reduce in their ability to catch food or avoid predators (LAIST, 1987; BAIRD; GORGONE, 2005). Although documentation is still sketchy, these impacts cannot be assumed to be negligible while human use of coastal ocean resources is increasing. Nonetheless, we note that the use photoidentification technique can be a tool to assess anthropogenic activities toward dolphins. It is important monitoring this population so that we can better assess the demographic impacts of these fisheries interactions on these dolphins.

\section{REFERENCES}

AZEVEDO, A. F.; LAILSON-BRITO, J.; DORNELES, P. R.; VAN SLUYS, M.; CUNHA, H. A.; FRAGOSO, A. B. L. Human-induced injuries to marine tucuxi (Sotalia guianensis) (Cetacea: Delphinidae) in Brazil. JMBA2 Biodiversity Records: 1-5, 2008. Published on line $<$ www.mba.ac.uk/jmba/biodiversityrecords,php?imbaref $=6191$.

BAIRD, R. W.; GORGONE, A. M. False killer whale dorsal fin disfigurements as a possible indicator of long-line fishery interactions in Hawaiian waters. Pacif. Sci., v. 59, p. 593-601, 2005.

BIGG, M. A.; ELLIS, G. M.; FORD, J. K. B.; BALCOMB, K. C. Killer whales: A study of their identification, genealogy, and natural history in British Columbia and Washington State. Nanaimo, British Columbia: Phantom Press, 1987.

DeMASTER, D.J.; FOWLER, C. W.; PERRY, S. L.; RICHLEN, M. E. Predation and competition: the impact of fisheries on marine mammal populations over the next one hundred years. J. Mammal., v. 82, p. 641-651, 2001.

FLORES, P. A. C. Tucuxi Sotalia fluviatilis In: PERRIN, W.F.; WÜRSIG, B.; THEWISSEN, G. M. (Ed.). Encyclopedia of marine mammals. San Diego: Academic Press, 2002. p. 1267-1269.

KOCK, K. H.; PURVES, M. G.; DUHAMEL, G. Interactions between Cetacean and Fisheries in the Southern Ocean. Polar Biol., v. 29, p. 379-388, 2006.

LAIST, D. W. Overview of the biological effects of lost and discarded plastic debris in the marine environment. Mar. Pollut. Bull., v. 18, p. 319-326, 1987.
LÓPEZ, A.; PIERCE, G. J.; SANTOS, M. B.; GRACIA, J.; GUERRA, A. Fishery by-catches of marine mammals in Galician waters: results from on-board observation and an interview survey of fishermen. Biol. Conserv., v. 111, p. 25-40, 2003.

MARQUES, A. N:- MORAES, R. B. C.; MAURAT, M. C. Poluição Marinha. In: PEREIRA, R. C.; SOARESGOMES, A. (Ed.). Biologia Marinha. Rio de Janeiro: Interciencia, 2002. p. 311-334.

MORGAN, M. A.; PATON, G. W. Human dolphin interactions on the west coast of Florida: Documentation from MML's Marine Mammal Response Program. Mote mar. Lab. Tech. Rept., v. 91: 1-9, 1990.

MUEHE, D.; VALENTINI, E. O litoral do Rio de Janeiro: uma caracterização físico-ambiental. Rio de Janeiro: FEMAR, 1998. $123 \mathrm{p}$.

NORMAN, F. I. Preliminary investigation on the bycatch of marine birds and mammals in inshore comercial fisheries, Victoria, Australia. Biol.Conserv., v. 92, p. 217-226, 2000.

PERRIN, W. F.; DONOVAN, G. P.; BARLOW, J. Gillnets and Cetaceans. International Whaling Commission , Special Issue, v. 15, p. 1-53, 1994.

READ, A. J.; DRINKER, P.; NORTHRIDGE, S. Bycatch of marine mammals in U.S. and global fisheries. Conserv. Biol., v. 20, p. 163-169, 2006.

REEVES, R. R.; SMITH, B. D.; CRESPO, E. A.; DI SCIARA, G. N. Dolphins, Whales and Porpoises: 2002-2010 Conservation Action Plan for the World's Cetaceans. IUCN/SSC Cetacean Specialist Group, Gland and Cambridge, 2003.

ROBBINS, J.; MATTILA, D. K. Monitoring entanglements of humpback whale (Megaptera novaeangliae) in the Gulf of Maine on the basis of caudal peduncle scarring. Document $\mathrm{SC} / 53 / \mathrm{NAH} 25$ presented to the International Whaling Commission Scientific Committee, 2001.

SIMÃO, S. M.; PIZZORNO, J. L. A.; PERRY, V. N.; SICILIANO, S. Aplicação da técnica de fotoidentificação do boto-cinza, Sotalia fluviatilis (Cetacea, Delphinidae) da Baía de Sepetiba. Floresta e Ambiente, v. 7, p. 31-39, 2000.

VISSER, I. N. Prolific body scars and collapsing dorsal fins on killer whales (Orcinus orca) in New Zealand water. Aquat. Mamm., v. 24, p. 71-78, 1998.

WELLS, R. S.; HOFMANN, S.; MOORS, T. L. Entanglement and mortality of bottlenose dolphins, Tursiops truncatus, in recreational fishing gear in Florida. Fish.Bull., v. 96, p. 647-650, 1998.

(Manuscript received 19 January 2008; revised 11 March 2008; accepted 15 August 2008) 